\title{
Effects of Natural Attenuation, Organic Amendments and Metal Toxicants on 2, 4- Dichlorophenoxyacetic Acid Dissipation Dynamics in Soil
}

\author{
Henrietta C Ogbu ${ }^{1,2}$, Raymond A Wuana ${ }^{2}$, John O Igoli \\ ${ }^{1}$ National Biotechnology Development Agency, Abuja 900107, Nigeria \\ ${ }^{2}$ Federal University of Agriculture, College of Science, Department of Chemistry and Centre for Agrochemical Technology, Makurdi \\ 970001, Nigeria
}

\begin{abstract}
The dissipation dynamics of the herbicide, 2,4-dichlorophenoxyacetic acid (2,4-D), in soil was studied under the influence of natural attenuation (NA), poultry manure (PM), swine manure (SM), urea (UR), and metal toxicants (Cd, Pb) in a laboratory microcosm. A sandy clay soil was characterized and used for the study. The effects of variables such as initial 2,4-D concentration (0 $500 \mathrm{mg} / \mathrm{kg})$, level of amendment $(0-30 \% \mathrm{w} / \mathrm{w})$, amendment blends (binary and ternary), Cd/Pb loadings $(0-200 \mathrm{mg} / \mathrm{kg})$ and incubation time (0 - 30 days) on 2,4-D dissipation were investigated. In all the experiments, residual 2,4-D was recovered by solvent extraction, followed by reaction with chromotropic acid reagent for color development and assayed by $U V$-Vis spectrophotometry at $\lambda_{\max } 565$ nm. 2,4-D naturally attenuated in soil, however, addition of PM, SM or UR did enhance the extent and rate of degradation. Relative to NA, the degrading efficiencies, $D E(\%)$ of the amendments increased with increase in incubation time and level of amendment, but did not necessarily depend on initial 2,4-D concentration. Pseudo-first-order degradation constants $\left(x 10^{-2} /\right.$ day) decreased with herbicide load and increased with amendment level; with corresponding half-lives (day) decreasing and increasing, respectively. DE values indicated that apart from the binary PM +SM amendment blend, the single amendments (especially PM and UR) were more effective at 2,4-D degradation in soil. The extent of 2,4-D degradation was reduced at increasing Cd and Pb loads, furnishing relatively low DE's ( $<50 \%)$ for the amendments but more so in the presence of $\mathrm{Cd}$ ).
\end{abstract}

Keywords: Biodegradation, 2, 4-dichlorophenoxyacetic acid, Natural attenuation, Poultry manure, Swine manure, Urea

\section{Introduction}

To maximize crop yield, ensure food security and economic benefits for sustaining the ever increasing world population, modern agriculture depends greatly on herbicides [1]. Herbicides are a subset of pesticides that kill or control weeds and pathogens that compete with valuable crop plants for soil, water, air, and nutrients [2]. Currently, herbicides represent over $70 \%$ of agrochemical imports worldwide and there are indications that they would continue to be the most employed agrochemicals [3]. Extensive use of herbicides, however, poses some far-reaching consequences because of the potential runoff and leaching of particularly the poorly degradable ones through the soil leading to contamination of surface and groundwater [4,5]. Herbicide residues may cause acute and genetic toxicity with attendant threat to the biota inhabiting the ecosystem. Literature suggests an array of possible toxicological implications of the persistent herbicides on the ecosystem [6].

The main chemical classes of herbicides include bipiridilium compounds, triazine derivatives such as atrazine, prometryn, propazin, etc), chlorophenoxy acid derivatives (2,4-D, 2,4,5T), substituted chloro-acetanilides (alachlor, propachlor), derivatives of 2,6-dinitroaniline (benfluralin, trifluralin), substituted phenylcarbamates (carbetamide, chlorbufam), urea derivatives (chlorbromuron, chlorotoluron), substituted sulphonylureas (amidosulfuron, trifusulfuron), etc [7, 8].

2,4-dichlorophenoxyacetic acid (2,4-D) is a herbicide from the group of polychlorinated aromatic hydrocarbons and one of the most widely used for the control of broad leaf weeds and grasses [9]. It is a synthetic auxin, and as such, often used in laboratories for plant research and as a supplement in plant cell culture media [10]. Although 2,4-D easily moves though the soil, its leaching into groundwater can be minimized due to degradation by microorganisms and also absorption by plants. Its primary route of degradation is by microorganisms, which increases with temperature, humidity, $\mathrm{pH}$, and organic matter content $[11-13]$.

The most important mechanism of microbial degradation involves the removal of the acetic acid side chain to yield 2,4-dichlorophenol, followed by ring cleavage and degradation to produce aliphatic acids such as succinic acid. The ability of micro-organisms to degrade herbicides has stimulated scientists to develop methods to assess the potential for the transformation of these anthropogenic chemicals via this route $[14,15]$. Consequently, several approaches such as bioventing, biostimulation, bioaugumentation, composting, bioremediation, etc have been put in place to cleanup herbicide residues in soil. The biostimulation approach is the practice of using fertilizers, manures, compost and other limiting factors to stimulate indigenous microorganisms for accelerated herbicide degradation in soil [15 - 17].

This study is aimed at assessing the dissipation dynamics of 2,4-D in soil under the influence of natural attenuation (NA) and/or poultry manure (PM), swine manure (SM), urea (UR), and two metal toxicants $(\mathrm{Cd}, \mathrm{Pb})$ in laboratory microcosms. The specific objectives were to check the effects of operating conditions such as initial 2,4-D concentration, amendment dosage, amendment blends (binary and ternary), metal 


\section{International Journal of Science and Research (IJSR) ISSN (Online): 2319-7064 \\ Index Copernicus Value (2013): 6.14 | Impact Factor (2014): 5.611}

toxicant $(\mathrm{Cd} / \mathrm{Pb})$ loadings, and incubation time on $2,4-\mathrm{D}$ dissipation in soil.

\section{Materials and Methods}

\subsection{Sample Collection, Pre-treatment and Characterization}

Ten top $(0-20 \mathrm{~cm})$ parent soil (PS) samples were randomly collected from the agricultural farm of the University of Agriculture, Makurdi $\left(7.44^{\circ} \mathrm{N}, 8.33^{\circ} \mathrm{E}\right)$, north-central Nigeria using a hand trowel. Raw poultry (PM) and swine (SM) manures were collected from animal farms in Makurdi and allowed to age for 2 weeks. Urea (UR) was supplied by NAFCON, Nigeria. The samples were put in polythene bags and taken to the laboratory. The samples were air-dried, ground, sieved $(<2 \mathrm{~mm})$, and the PS composited. Standard operating procedures were used to test the PS, PM SM and UR for $\mathrm{pH}$ (1:25 soil/water ratio) [18], particle size distribution [19]; organic carbon/matter [20], total nitrogen [21], total phosphorus [22], and total $\mathrm{Cd}$ and $\mathrm{Pb}$ [23], as the case may be. Isolation and identification of bacteria and fungi were done according to the method described by Swift and Bignell [24].

\subsection{Laboratory Microcosms to Monitor 2,4-D Dissipation in Soil}

A concentrate of 2,4-D, Aminoforce (2,4dimethylammonium salt, specific gravity $=0.72 \mathrm{~g} / \mathrm{mL}$, see Figure 1 for chemical structure) was supplied by Jubaili Agrotech Ltd. A $5000 \mathrm{mg} / \mathrm{L}$ 2,4-D stock was prepared by pipetting a $6.944 \mathrm{~mL}$ aliquot of the concentrate into a $1 \mathrm{~L}$ volumetric flask and the solution made up to the mark with distilled water. Thus $1.0 \mathrm{~mL}$ of this stock was equivalent to 5 $\mathrm{mg}$ of 2,4-D.

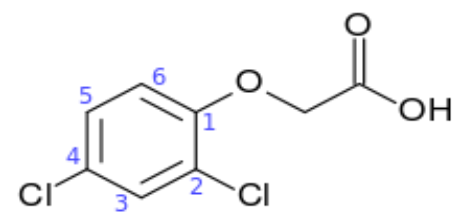

Figure 1: Chemical structure of 2,4-D

(2,4-Dichlorophenoxyacetic acid)

In order to study the effect of initial 2,4-D concentration on its degradation in soil under natural attenuation (NA), PS was fortified with known concentrations of the herbicide, $\mathrm{C}_{\mathrm{o}}$ $(\mathrm{mg} / \mathrm{kg})$, and its degradation was monitored as a function of time (day). Aliquots V (mL) of the 2,4-D stock, were used to spike fixed weights of PS, w (g) with 2,4-D to achieve $0 \leq \mathrm{C}_{\mathrm{o}}(\mathrm{mg} / \mathrm{kg}) \leq 500$ levels with the aid of Equation (1):

$$
C_{\mathrm{o}}(\mathrm{mg} / \mathrm{kg})=\frac{5(\mathrm{mg})}{(\mathrm{mL})} \times \frac{V(\mathrm{~mL})}{10^{3}(\mathrm{~g})} \times \frac{10^{3}(\mathrm{~g})}{1(\mathrm{~kg})} \times \frac{10^{3}(\mathrm{~g})}{w(\mathrm{~g})}
$$

More precisely, to separate fixed weights ( $\mathrm{w}=25 \mathrm{~g})$ of the PS; $0,0.5,1.0,1.5,2.0$ and $2.5 \mathrm{~mL}$ of the $5000-\mathrm{mg} / \mathrm{L} 2,4-\mathrm{D}$ stock solution were added to achieve $0,100,200,300,400$ and $500 \mathrm{mg} / \mathrm{kg}$ levels of artificial contamination with the herbicide. The set up was equilibrated for 5, 10, 20 and 30 days under NA.
The effect of 2,4-D concentration on its dissipation in amended soil was studied by adding aliquots of the 2,4-D stock $(5000-\mathrm{mg} / \mathrm{L})$ to separate fixed weights $(\mathrm{w}=25 \mathrm{~g})$ of the PS to furnish $0 \leq \mathrm{C}_{\mathrm{o}}(\mathrm{mg} / \mathrm{kg}) \leq 500$ levels. The different set ups were treated with $2.78 \mathrm{~g}$ of PM, SM or UR to achieve 10 $\% \mathrm{w} / \mathrm{w}$ amendment. Each microcosm was incubated for 5 , 10,20 and 30 days.

In microcosms designed to check the effect of level of organic amendment on 2,4-D dissipation in soil, increasing levels of PM, SM or UR were added to the herbicidefortified PS $(500 \mathrm{mg} / \mathrm{kg})$ at 5, 10, 15, 20 and $30 \% \mathrm{w} / \mathrm{w}$ and set up allowed to equilibrate for 5, 10, 20 and 30 days.

The effect of amendment blends on 2,4-D dissipation in soil was assessed by treating the herbicide-fortified $(500 \mathrm{mg} / \mathrm{kg})$ PS soil subsamples with different blends of the amendments $(\mathrm{PM}+\mathrm{SM}, \mathrm{PM}+\mathrm{UR}, \mathrm{SM}+\mathrm{UR}$ or $\mathrm{PM}+\mathrm{SM}+\mathrm{UR})$ at a fixed dose $(10 \% \mathrm{w} / \mathrm{w})$. Specifically, the binary blends were formulated at ratios of 1:1 (i.e., $1.39 \mathrm{~g}: 1.39 \mathrm{~g}$ ); while the ternary blend was got by combining the amendments in the ratio 1:1:1 (i.e, $0.9259 \mathrm{~g}: 0.9259 \mathrm{~g}: 0.9259 \mathrm{~g}$ ). The microcosms were left to stand under ambient conditions for $5,10,20$ and 30 days.

Finally, the influence of two metal toxicants $(\mathrm{Cd}$ and $\mathrm{Pb})$ on 2,4-D dissipation in amended soil was investigated by first, treating the herbicide-spiked $(500 \mathrm{mg} / \mathrm{kg})$ PS subsamples singly with PM, SM, or UR at a fixed dose $(10 \% \mathrm{w} / \mathrm{w})$. Next, $\mathrm{Cd}$ and $\mathrm{Pb}$ (in form of their nitrates dissolved in deionized water) were added at increasing doses $(10,50,100,150$ and $200 \mathrm{mg} / \mathrm{kg}$ ) and the set ups incubated for 2 weeks (14 days). This procedure was repeated under the NA scenario (i.e., without the amendments). In all microcosms, the residual 2,4-D was extracted at the elapse of a specified incubation time and assayed by UV-vis spectrophotometry.

\subsection{Solvent Extraction 2,4-D Recovery in Soil and Formation of Calibration Curve for UV-vis Spectrophotometric Determination}

Solvent extraction of 2,4-D in soil was done using the colorimetric procedure described by Durga Devi et al. [25]. Colorimetry is one of the earliest and instrumental techniques for the estimation of 2,4-D residues, and even today it continues to be a useful and facile method wherever costlier modern facilities like gas chromatograph are not readily available. Soil samples were shaken with solvents (acetonitrile: distilled water: glacial acetic acid (80:20:2.5) at soil:solvent ratios of 1:2 for a period of $30 \mathrm{~min}$. That is, 10 $\mathrm{mL}$ of the mixed solvent were added to $5 \mathrm{~g}$ soil and then shaken for 30 min with the aid of a mechanical shaker (Milano, Italia). The filtrate was shaken with $50 \mathrm{~mL} 1.0 \mathrm{M}$ $\mathrm{NaOH}, 7.5 \mathrm{~mL}$ concentrated $\mathrm{HCl}$ and $25 \mathrm{~mL}$ of diethyl ether in a $250 \mathrm{~mL}$ separating funnel. The ether portion was separated and the aqueous layer was again shaken with 25 $\mathrm{mL}$ diethyl ether. The ether portions were pooled and extracted twice with $12.5 \mathrm{~mL}$ of buffer solution (25 g $\mathrm{Na}_{2} \mathrm{HPO}_{4} \cdot 12 \mathrm{H}_{2} \mathrm{O}$ and $10 \mathrm{~g} \mathrm{NaH}{ }_{2} \mathrm{PO}_{4} \cdot \mathrm{H}_{2} \mathrm{O}$ in $1 \mathrm{~L}$ of distilled water). The pooled buffer separate was shaken with $0.5 \mathrm{~mL}$ concentrated $\mathrm{HCl}$ and $5 \mathrm{~mL}$ carbon tetrachloride. The aqueous layer was separated and again shaken with $5 \mathrm{~mL}$ carbon tetrachloride. The combined carbon tetrachloride 


\section{International Journal of Science and Research (IJSR) \\ ISSN (Online): 2319-7064 \\ Index Copernicus Value (2013): 6.14 | Impact Factor (2014): 5.611}

layer was evaporated and the residue was treated with 1.5 $\mathrm{mL}$ chromotropic acid reagent $(0.4 \mathrm{~g}$ chromotropic acid in $100 \mathrm{~mL}$ of concentrated $\mathrm{H}_{2} \mathrm{SO}_{4}$ ) and kept in an oven at 120 ${ }^{\circ} \mathrm{C}$ for $20 \mathrm{~min}$. The wine purple colored complex obtained was cooled, diluted and made up to $25 \mathrm{~mL}$ with distilled water. It was transferred into another bottle and made up to $100 \mathrm{~mL}$ with distilled water. Absorbance of the colored complex was read on a UV-vis spectrophotometer (Jenway $6705)$ at $\lambda_{\max } 565 \mathrm{~nm}$ against a reagent blank.

A standard absorption curve for 2,4-D acid was prepared by diluting $0,0.5,1.0,1.5,2.0$ and $2.5 \mathrm{~mL}$ of the $5000 \mathrm{mg} / \mathrm{L}$ 2,4-D stock in distilled water (equivalent to 0, 100, 200, 300, 400 and $500 \mathrm{mg}$ 2,4-D per $\mathrm{kg}$ of soil) and the color was developed using the same procedure as for soil sample. The calibration curve (Figure 2) was constructed so that the absorbance (A) readings obtained from the experiments could be directly converted into residual 2,4-D concentration, $\mathrm{C}_{\mathrm{res}}$ in soil $(\mathrm{mg} / \mathrm{kg})$ by extrapolating through the linearity range (slope $=1.20 \times 10^{-3} \mathrm{~kg} / \mathrm{mg}$ ) with the aid of Equation (2):

$$
C_{\text {res }}(\mathrm{mg} / \mathrm{kg})=\frac{A(\mathrm{mg})}{\text { slope }(\mathrm{kg})} x \frac{w(\mathrm{~g})}{y(\mathrm{~g})}
$$

where $\mathrm{w}$ and $\mathrm{y}$ are the total weight of 2,4-D-spiked soil $(25$ g) and aliquot of the spiked soil taken for 2,4-D assay (5 g), respectively.

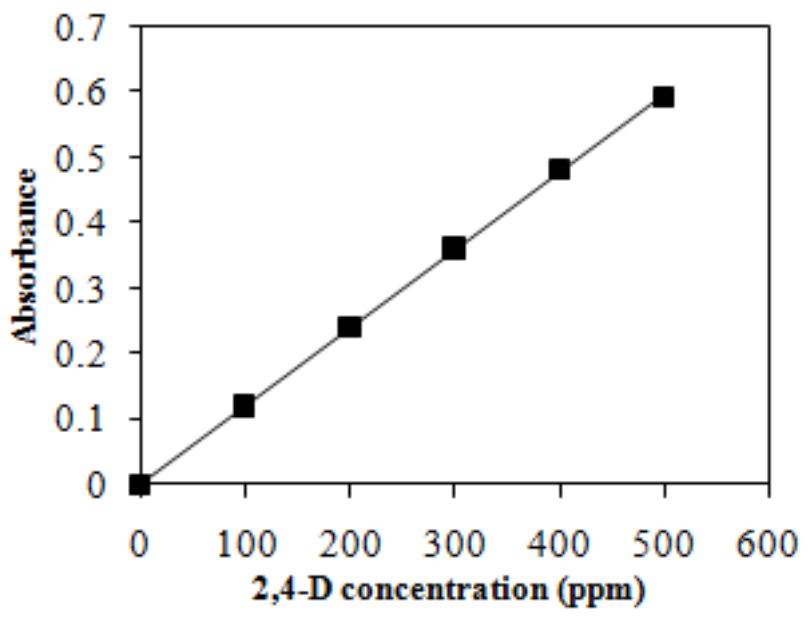

Figure 2: Calibration curve for UV-vis Spectrophotometric Determination of 2,4-D in Soil $\left(\lambda_{\max } 565 \mathrm{~nm}\right)$

\subsection{Quality Control/Assurance and Data Handling}

Analytical grade chemicals were used to prepare standard solutions and reagents. All glassware and plastics were washed with distilled water, rinsed with $(1+1) \mathrm{HNO}_{3}$ and finally with distilled water. Procedural blank samples were subjected to similar treatments using the same amounts of reagents. In all cases, measurements were performed in triplicates. A Microsoft ${ }^{\circledR}$ Excel 2010 package was used to perform all algorithm plots and calculations. The percent degradation or degradation yield, DY (\%), taken as a measure of the extent of degradation was calculated by:

$$
D Y(\%)=\left(\frac{C_{\mathrm{o}}-C_{\mathrm{res}}}{C_{\mathrm{o}}}\right) x 100
$$

where $\mathrm{C}_{\mathrm{o}}$ is the initial herbicide concentration in soil $(\mathrm{mg} / \mathrm{kg})$ and $\mathrm{C}_{\text {res }}$ is the residual herbicide in soil $(\mathrm{mg} / \mathrm{kg})$ after a specified incubation time.

The biodegradation of modelled by pseudo-first order kinetics ${ }_{9}$, a typical algorithm for which is given by:

$$
C_{\text {res }}=C_{\mathrm{o}} \exp ^{-k_{1} t}
$$

where $\mathrm{C}_{\mathrm{o}}$ and $\mathrm{C}_{\text {res }}$ are as defined in Eq. 3 ; $\mathrm{t}$ is the incubation time (day). $\mathrm{k}_{1}$ is the biodegradation rate constant $\left(\right.$ day $\left.^{-1}\right)$. In practice, $\mathrm{k}_{1}$ was obtained from the slope of the least-squares regression equation resulting from the plot of $\operatorname{lnC}_{\text {res }}$ versus $t$. The biodegradation half-life, $\tau_{1 / 2}$ (day), i.e., time taken for herbicide to degrade by one-half of its initial concentration in soil was calculated as:

$$
\tau_{1 / 2}=\frac{0.693}{k_{1}}
$$

The half life model is based on the assumption that the biodegradation rate of herbicides is positively correlated with the herbicide pool size in soil and may be applied during chemical screening, environmental fate modelling and description of the transformation of the herbicide in soil. The 2,4-D degrading efficiency, DE (\%) of a particular amendment was calculated as:

$$
\operatorname{DE}(\%)=\left(\frac{C_{\mathrm{res}(\mathrm{u})}-C_{\mathrm{res}(\mathrm{a})}}{C_{\mathrm{res}(\mathrm{u})}}\right) x 100
$$

where $C_{\text {res(u) }}$ is the residual 2,4-D concentration $(\mathrm{mg} / \mathrm{kg})$ in the unamended soil (i.e., under NA) and $\mathrm{C}_{\text {res(a) }}$ is the corresponding concentration in the amended soil $(\mathrm{mg} / \mathrm{kg})$.

\section{Results and Discussion}

\subsection{Physicochemical Characteristics of Parent Soil and Organic Amendments}

Some physicochemical properties of the parent soil and organic amendments used for the study are given in Table 1. The PS, PM, SM and UR had $\mathrm{pH}$ values of 5.98, 6.95, 6.99 and 7.80 , respectively all in the range reported for typical agricultural soils and the amendments [26, 27]. Texturally, the sand, silt and clay fractions in the PS were 82.86, 3.28 and $13.85 \%$, respectively qualifying it as sandy clay. The particle size distribution of the soil suggests a low waterretention capacity and possible short- and long-term herbicide leachability. The respective organic matter content of the PS, PM, SM and UR were 1.36, 38.16, 38.53 and $0.25 \%$, corresponding to organic $\mathrm{C}$ contents of $0.79,22.07$, 22.29 and 0.14 . The organic matter content of the PS qualifies it as a mineral soil, a typical characteristic of most agricultural soils. The $\mathrm{C}: \mathrm{N}$ ratio of 4.64 for the PS is rather low for effective herbicide mineralization, hence the need for supplementation with the organic amendments, especially 


\section{International Journal of Science and Research (IJSR) \\ ISSN (Online): 2319-7064}

Index Copernicus Value (2013): 6.14 | Impact Factor (2014): 5.611

$\mathrm{PM}(\mathrm{C}: \mathrm{N}=10.50)$ and $\mathrm{SM}(\mathrm{C}: \mathrm{N}=7.69)$. The appreciable quantities of $\mathrm{N}$ and $\mathrm{P}$ in the amendments are necessary nutrients for bacterial biodegradative activities [28]. PM had the highest $\mathrm{C}$ content among the organic wastes and high $\mathrm{N}$ content, the most important limiting nutrient for effective biodegradation to take place [29].

The ranges of total $\mathrm{Cd}$ and $\mathrm{Pb}(\mathrm{mg} / \mathrm{kg})$ in the $\mathrm{PS}$ and the amendments were: $\mathrm{Cd}(0.31-0.37)$ and $\mathrm{Pb}(0.31-0.35)$. These values are lower than their corresponding upper critical levels, defined as the range of values above which toxicity is considered to be possible [30], indicating that the PS and the amendments were relatively uncontaminated in terms of $\mathrm{Cd}$ and $\mathrm{Pb}$. The bacteria identified in PS were Bacillus spp and Norcardia spp; while the fungal species were A. fumigates, Penicillium spp., and Streptomyces spp.

Table 1: Some physicochemical attributes of parent soil and organic amendments*

\begin{tabular}{|c|c|c|c|c|}
\hline Parameter & $P S$ & $P M$ & $S M$ & $U R$ \\
\hline $\mathrm{pH}$ & 5.98 & 6.95 & 6.99 & 7.80 \\
\hline Sand (\%) & 82.86 & - & - & - \\
\hline Silt (\%) & 3.28 & - & - & - \\
\hline Clay (\%) & 13.85 & - & - & - \\
\hline Organic matter (\%) & 1.36 & 38.16 & 38.35 & 0.25 \\
\hline Organic carbon (\%) & 0.79 & 22.07 & 22.29 & 0.14 \\
\hline $\mathrm{N} \mathrm{(mg/kg)}$ & 0.17 & 2.10 & 2.90 & 45.58 \\
\hline $\mathrm{P}(\mathrm{mg} / \mathrm{kg})$ & 9.28 & 1.80 & 0.90 & - \\
\hline Total Cd (mg/kg) & 0.39 & 0.37 & 0.31 & - \\
\hline Total $\mathrm{Pb} \mathrm{(mg/kg)}$ & 0.35 & 0.30 & 0.31 & - \\
\hline
\end{tabular}

$*$ PS $=$ Parent soil, PM $=$ Poultry manure, $\mathrm{SM}=$ Swine manure, $\mathrm{UR}=$ Urea

\subsection{Effect of Initial 2,4-D Concentration and Incubation Time on its Dissipation in Soil}

At the $(100-500 \mathrm{mg} / \mathrm{kg})$ initial 2,4-D concentrations studied, the rate of disappearance of 2,4-D per unit time, $\mathrm{R}(\mathrm{t})$ $\left(\mathrm{mg} / \mathrm{kg}\right.$.day) between $t_{1}$ and $t_{2}$ (where $t_{1}<t_{2}$ ), decreased with time, but increased at successively higher herbicide loads (Figure 3). A similar trend was found for the microbial degradation of 2,4-D by Burkholderia cepacia, Pseudomonas sp. and Sphingomonas paucimobilis [9]. Several transformation pathways such as hydrolysis, methylation and ring cleavage have been suggested for 2,4-D mineralization [10]. Seemingly, the extent of 2,4-D dissipation levelled up, after the 30 days of incubation. Conversely, the extent of herbicide degradation, DY increased with time, decreased with increasing herbicide load and ranged as: NA (29.18 $87.38 \%)$, PM (39.04 - 94.87\%); SM (32.97 - 90.93\%); and UR (36.87 - 93.67). Under the single amendment scenarios, both $\mathrm{R}(\mathrm{t})$ and DY increased in the order: NA $>\mathrm{SM}>\mathrm{UR}>$ PM. The degrading efficiency of the amendments, DE (\%) (calculated relative to the NA media) generally increased with increase in incubation time, but seemingly did not depend on $\mathrm{C}_{\mathrm{o}}$.

Typical DE ranges for the single amendments were in the order: $\mathrm{PM}[13.50 \leq \mathrm{DE}(\%) \leq 61.97]>\mathrm{UR}[7.73 \leq \mathrm{DE}(\%) \leq 49.84]$ $>\mathrm{SM}[4.67 \leq \mathrm{DE}(\%) \leq 34.99]$.
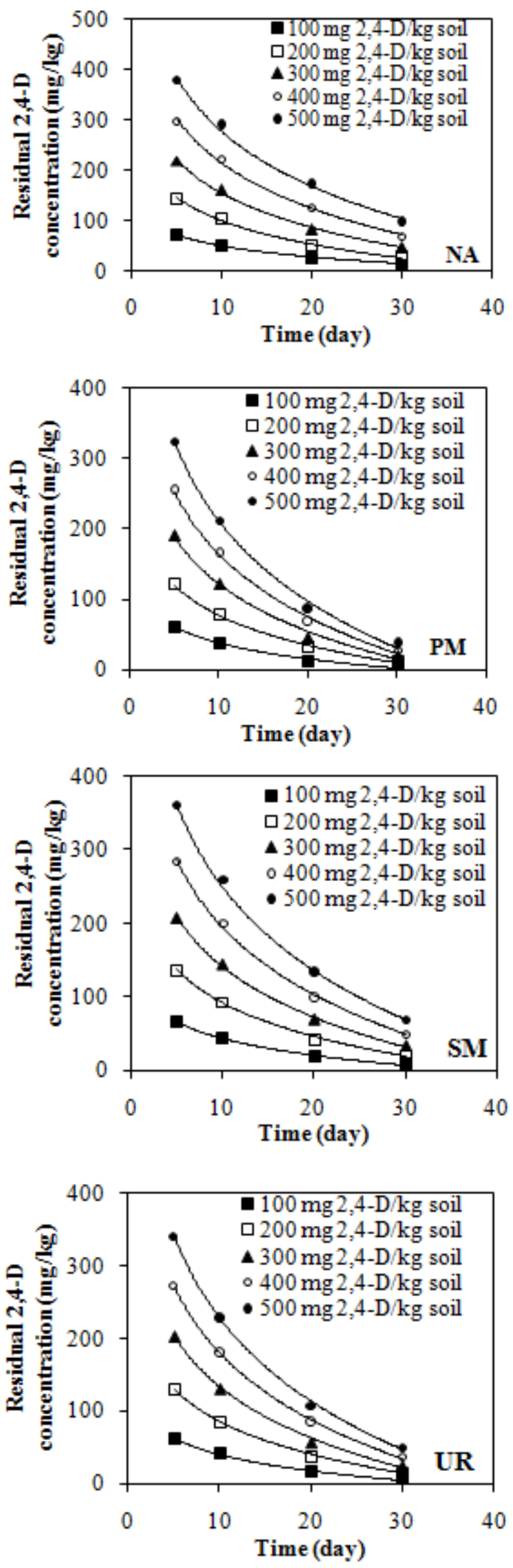

Figure 3: Dissipation of 2,4-D with time in soils with different herbicide loadings under natural attenuation (NA) or treatment with $(10 \% \mathrm{w} / \mathrm{w})$ poultry manure $(\mathrm{PM})$, swine manure (SM) and urea (UR) 


\section{International Journal of Science and Research (IJSR) \\ ISSN (Online): 2319-7064 \\ Index Copernicus Value (2013): 6.14 | Impact Factor (2014): 5.611}

The values of $\mathrm{k}_{1}\left(\mathrm{x} 10^{-2} /\right.$ day) decreased with herbicide load;

while those of $\tau_{1 / 2}$ (day) increased correspondingly. Typical ranges of the kinetic parameters were: NA $\left[5.4 \leq \mathrm{k}_{1} \leq 0.68\right.$; $\left.10.2 \leq \tau_{1 / 2} \leq 12.8\right], \quad$ PM $\quad\left[8.7 \leq \mathrm{k}_{1} \leq 10.0 ; \quad 6.9 \leq \tau_{1 / 2} \leq 8.0\right] ; \quad \mathrm{SM}$ $\left[6.4 \leq \mathrm{k}_{1} \leq 8.1 ; \quad 8.6 \leq \tau_{1 / 2} \leq 10.9\right] ; \quad$ and $\quad$ UR $\quad\left[7.6 \leq \mathrm{k}_{1} \leq 9.2\right.$; $\left.7.5 \leq \tau_{1 / 2} \leq 9.1\right]$.

Table 2: 2,4-D degradation rate constants $\left(\mathrm{k}_{1}\right)$ and half-lives $\left(\tau_{1 / 2}\right)$ in soils with different herbicide loadings under natural attenuation (NA) or treatment with $(10 \% \mathrm{w} / \mathrm{w})$ poultry manure (PM), swine manure (SM) and urea (UR)

\begin{tabular}{|c|c|c|c|c|}
\hline Treatment & $\begin{array}{c}\text { Initial 2,4-D load } \\
(\mathrm{mg} / \mathrm{kg})\end{array}$ & $\begin{array}{c}k_{1} \\
\left(10^{-2} / \text { day }\right.\end{array}$ & $\begin{array}{c}t_{1 / 2} \\
(\text { day })\end{array}$ & $R^{2}$ \\
\hline \multirow{4}{*}{ NA } & 100 & 6.80 & 10.19 & 0.999 \\
\cline { 2 - 5 } & 200 & 6.60 & 10.50 & 0.998 \\
\cline { 2 - 5 } & 300 & 6.20 & 11.18 & 0.999 \\
\cline { 2 - 5 } & 400 & 5.80 & 11.95 & 0.999 \\
\cline { 2 - 5 } & 500 & 5.40 & 12.84 & 0.999 \\
\hline \multirow{4}{*}{ PM } & 100 & 10.00 & 6.93 & 0.995 \\
\cline { 2 - 5 } & 200 & 9.70 & 7.15 & 0.996 \\
\cline { 2 - 5 } & 300 & 9.10 & 7.62 & 0.999 \\
\cline { 2 - 5 } & 400 & 8.90 & 7.79 & 0.999 \\
\hline \multirow{4}{*}{ SM } & 500 & 8.70 & 7.97 & 0.999 \\
\cline { 2 - 5 } & 100 & 8.10 & 8.56 & 0.997 \\
\cline { 2 - 5 } & 200 & 7.60 & 9.12 & 0.998 \\
\cline { 2 - 5 } & 300 & 7.20 & 9.63 & 0.999 \\
\cline { 2 - 5 } & 400 & 6.70 & 10.35 & 0.993 \\
\hline \multirow{4}{*}{ UR } & 500 & 6.40 & 10.85 & 0.999 \\
\cline { 2 - 5 } & 100 & 9.20 & 7.53 & 0.997 \\
\cline { 2 - 5 } & 200 & 8.50 & 8.15 & 0.999 \\
\cline { 2 - 5 } & 300 & 8.30 & 8.35 & 0.998 \\
\cline { 2 - 5 } & 400 & 7.90 & 8.77 & 0.999 \\
\hline & 500 & 7.60 & 9.12 & 0.999 \\
\hline
\end{tabular}

\subsection{Effect of Level of Organic Amendment on 2,4-D Dissipation in Soil}

At the levels of amendments $(5 \leq \% \mathrm{w} / \mathrm{w} \leq 30)$ under study, $\mathrm{R}(\mathrm{t})$ decreased with increase in both incubation time and level of amendment (Figure 4). DY, on the other hand, increased with both incubation time and herbicide load such that, at the elapse of the 30-day incubation, minimum and maximum degradation yields were: PM (27.75 and 94.87\%); SM (25.17 and 90.93\%); and UR (29.18 and 93.67\%). Both R(t) and DY increased in the order: SM $>$ UR $>$ PM.

Under the single amendment scenario, DE generally increased with increase in incubation time and level of amendment. Typical DE ranges at the operating levels of amendments were: PM $\quad[4.87 \leq \mathrm{DE}(\%) \leq 98.71]$; $\quad$ UR $[6.76 \leq \mathrm{DE}(\%) \leq 70.77]$; and $\mathrm{SM}[1.49 \leq \mathrm{DE}(\%) \leq 70.16]$.

The values of $\mathrm{k}_{1}$ increased with increase in level of amendment, but a converse trend was observed for corresponding values of $\tau_{1 / 2}$ (day), which decreased with increase in amendment level (Table 3). Depending on the type of amendment, the range of the kinetic parameters were: PM $\left(6.60 \leq \mathrm{k}_{1} \leq 20.10 ; 3.45 \leq \tau_{1 / 2} \leq 10.50\right) ;$ SM $\quad\left(5.90 \leq \mathrm{k}_{1} \leq 9.50\right.$; $\left.7.30 \leq \tau_{1 / 2} \leq 11.75\right)$; and UR $\left(6.90 \leq \mathrm{k}_{1} \leq 9.50 ; 7.30 \leq \tau_{1 / 2} \leq 10.05\right)$.

Overall, the magnitude of DY, DE and the kinetic parameters $\left[R(t), k_{1}\right.$ and $\left.\tau_{1 / 2}\right]$ indicated that among the amendments PM proved more efficient at 2,4-D dissipation in soil.
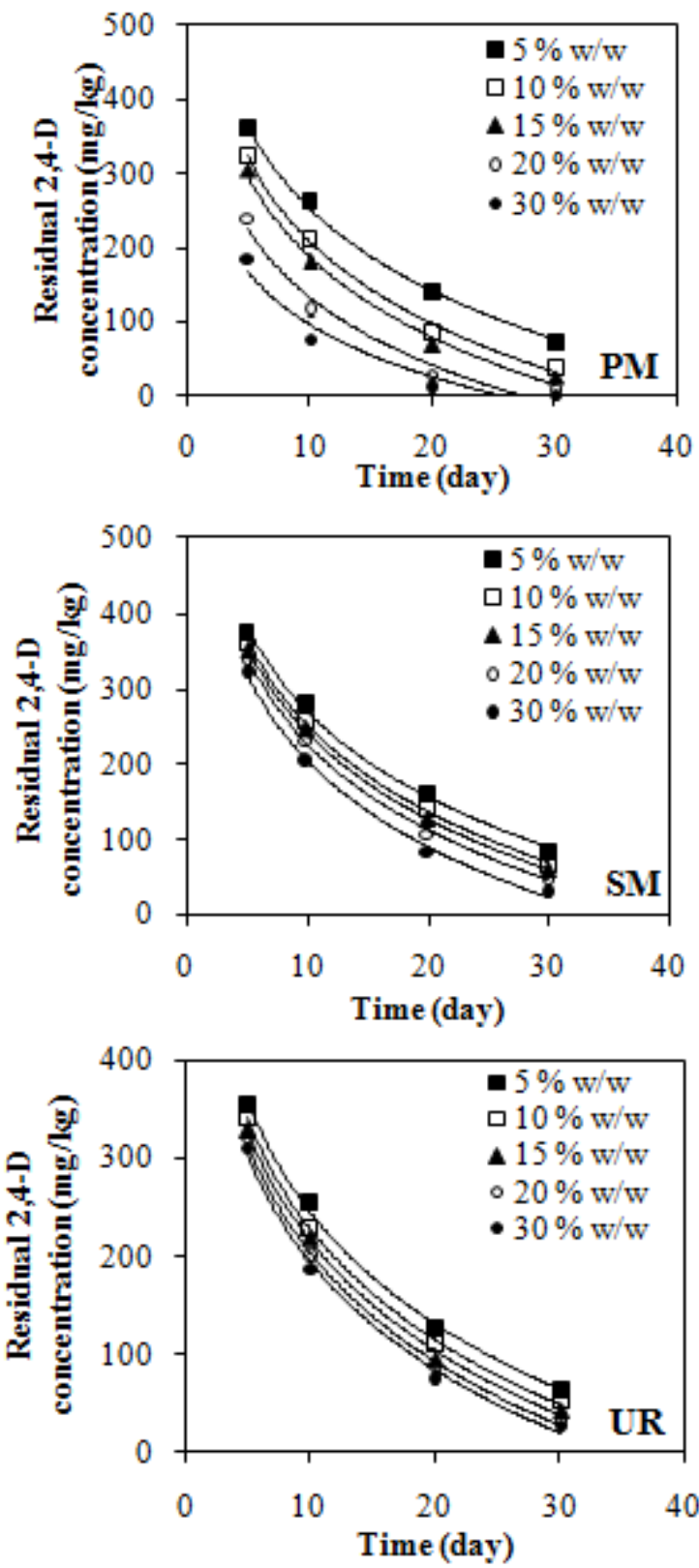

Figure 4: Dissipation of 2,4-D with time in soils loaded with herbicide $(500 \mathrm{mg} / \mathrm{kg})$ and different doses of poultry manure $(\mathrm{PM})$, swine manure (SM) and urea (UR)

Table 3: 2,4-D degradation rate constants $\left(\mathrm{k}_{1}\right)$ and half-lives $\left(\tau_{1 / 2}\right)$ in soils with herbicide $(500 \mathrm{mg} / \mathrm{kg})$ at different doses of poultry manure (PM), swine manure (SM) and urea (UR)

\begin{tabular}{|c|c|c|c|c|}
\hline \multirow{3}{*}{ Treatment } & $\begin{array}{c}\text { Amendment dose } \\
(\% \mathrm{w} / \mathrm{w})\end{array}$ & $\begin{array}{c}k_{1} \\
\left(10^{-2} / \text { day }\right.\end{array}$ & $\begin{array}{c}t_{1 / 2} \\
(\text { day })\end{array}$ & $R^{2}$ \\
\hline \multirow{4}{*}{ PM } & 5 & 6.60 & 10.50 & 0.999 \\
\cline { 2 - 5 } & 10 & 8.70 & 7.97 & 0.999 \\
\cline { 2 - 5 } & 15 & 9.80 & 7.07 & 0.999 \\
\cline { 2 - 5 } & 20 & 14.90 & 4.65 & 0.998 \\
\hline \multirow{4}{*}{ SM } & 30 & 20.10 & 3.45 & 0.999 \\
\cline { 2 - 5 } & 5 & 5.90 & 11.75 & 0.998 \\
\cline { 2 - 5 } & 10 & 6.80 & 10.19 & 0.997 \\
\cline { 2 - 5 } & 15 & 7.00 & 9.90 & 0.999 \\
\hline \multirow{4}{*}{ UR } & 20 & 7.90 & 8.77 & 0.999 \\
\cline { 2 - 5 } & 30 & 9.50 & 7.39 & 0.997 \\
\cline { 2 - 5 } & 5 & 7.90 & 10.05 & 0.996 \\
\cline { 2 - 5 } & 10 & 8.20 & 9.24 & 0.992 \\
\cline { 2 - 5 } & 15 & 9.00 & 7.70 & 0.999 \\
\hline & 20 & 9.50 & 7.30 & 0.999 \\
\hline
\end{tabular}




\section{International Journal of Science and Research (IJSR) \\ ISSN (Online): 2319-7064 \\ Index Copernicus Value (2013): 6.14 | Impact Factor (2014): 5.611}

\subsection{Effect of Amendment Blends on 2,4-D Dissipation in Soil}

In the presence of the different amendment blends (binary and ternary), $\mathrm{R}(\mathrm{t})$ still decreased with increase in time (Figure 5); while DY followed the converse trend ranging as: $\mathrm{PM}+\mathrm{SM}(39.92-95.00 \%) ; \mathrm{PM}+\mathrm{UR}(29.86-87.84 \%)$; SM + UR (24.75 - 82.36\%); and PM + SM + UR (28.30$84.72 \%)$. DE increased with increase in incubation time and actual ranges were: PM + SM $(20.90-73.90 \%) ; \mathrm{PM}+\mathrm{UR}$ $(7.65-36.66 \%) ; \mathrm{SM}+\mathrm{UR}(0.92-8.18 \%)$; and PM + SM + UR (5.61 - 20.14\%). Based on DE values, it can be inferred that, apart from the binary PM + SM amendment blend, the single amendments were superior at 2,4-D degradation in soil.

Accordingly (Table 4), the following kinetic parameters were furnished for the various amendment blends: $\mathrm{PM}+\mathrm{SM}\left(\mathrm{k}_{1}=\right.$ $\left.14.90, \tau_{1 / 2}=4.65\right) ; \mathrm{PM}+\mathrm{UR}\left(\mathrm{k}_{1}=9.8, \tau_{1 / 2}=7.07\right) ; \mathrm{PM}+\mathrm{SM}$ $+\operatorname{UR}\left(\mathrm{k}_{1}=8.7, \tau_{1 / 2}=7.97\right)$ and SM $+\mathrm{UR}\left(\mathrm{k}_{1}=6.60, \tau_{1 / 2}=\right.$ 10.50). Overall, it seemed that the single PM and binary PM + SM scenarios were most efficient at 2,4-D dissipation in the experimental soil.

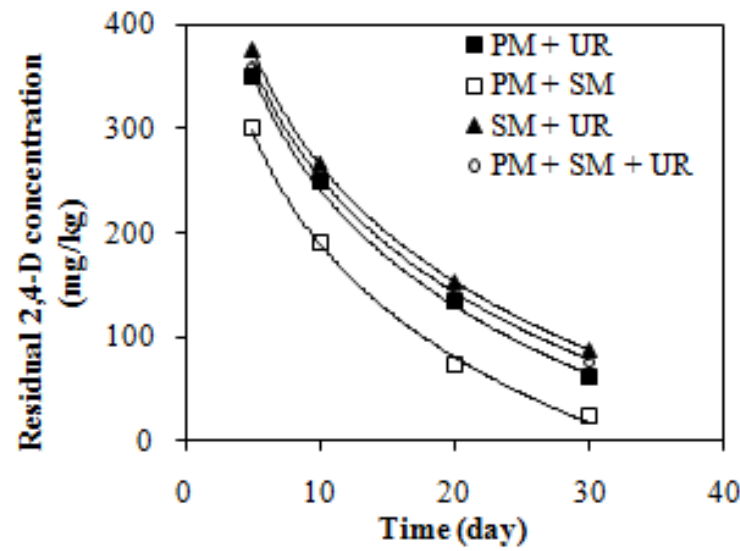

Figure 5: Dissipation of 2,4-D with time in soils with herbicide $(500 \mathrm{mg} / \mathrm{kg})$ and different blends of $10 \% \mathrm{w} / \mathrm{w}$ poultry manure (PM), swine manure (SM) and urea (UR)

Table 4: 2,4-D degradation rate constants $\left(\mathrm{k}_{1}\right)$ and half-lives $\left(\tau_{1 / 2}\right)$ in soils with herbicide $(500 \mathrm{mg} / \mathrm{kg})$ and different blends $(10 \% \mathrm{w} / \mathrm{w})$ of poultry manure (PM), swine manure (SM) and

\begin{tabular}{|c|c|c|c|}
\multicolumn{4}{c}{ urea (UR). } \\
\hline Treatment & $\begin{array}{c}k_{1} \\
\left(10^{-2} / \text { day }\right.\end{array}$ & $\begin{array}{c}t_{1 / 2} \\
(\text { day })\end{array}$ & $R^{2}$ \\
\hline PM + SM & 14.90 & 4.65 & 0.998 \\
\hline PM + UR & 9.80 & 7.07 & 0.997 \\
\hline SM + UR & 6.60 & 10.50 & 0.998 \\
\hline PM + SM + UR & 8.70 & 7.97 & 0.999 \\
\hline
\end{tabular}

\subsection{Effect of Metal Toxicants (Cd and $\mathrm{Pb}$ ) on 2,4-D Dissipation in Soil}

Figure 6 illustrates the effect of different doses $\left(\mathrm{C}_{\mathrm{M}}\right)$ of $\mathrm{Cd}$ or $\mathrm{Pb}\left[10 \leq \mathrm{C}_{\mathrm{M}}(\mathrm{mg} / \mathrm{kg}) \leq 200\right]$ on the dissipation of $2,4-\mathrm{D}\left(\mathrm{C}_{\mathrm{o}}=\right.$ $500 \mathrm{mg} / \mathrm{kg}$ ) in soil studied under NA and treatment with $(10 \% \mathrm{w} / \mathrm{w}) \mathrm{PM}, \mathrm{SM}$, and UR after 2 weeks of incubation.
Under NA and in the absence of $\mathrm{Cd}$ or $\mathrm{Pb}, 54.82 \%$ of $2,4-\mathrm{D}$ was degraded after 2 weeks (Figure 2). DY was, however, suppressed in the presence of metal toxicants and decreased with increasing $\mathrm{Cd}$ and $\mathrm{Pb}$ doses. Typical $\mathrm{DY}$ ranges were: $30.52-47.46 \%$ for the NA-Cd and $37.88-53.48 \%$ for the $\mathrm{NA}-\mathrm{Pb}$ scenario. In the presence of PM and metal toxicants, DY was $57.94-68.18 \%$ and $64.42-68.18 \%$ for the PM-Cd and $\mathrm{PM}-\mathrm{Pb}$ microcosms, respectively. For SM, 55.88 $58.88 \%$ and $57.46-60.00 \%$ of $2,4-\mathrm{D}$ were degraded in the presence of SM-Cd and SM-Pb, respectively. Addition of UR achieved $60.88-64.00 \%$ and $62.82-64.72 \%$ of $2,4-\mathrm{D}$ dissipation for the UR-Cd and UR-Pb media, respectively.

Relative to the NA-metal toxicant media, the ranges of DE were: PM-Cd (32.51 - 42.55\%), PM-Pb (32.09 - 42.72\%); SM-Cd (21.74 - 36.50\%), SM-Pb (13.83 - 31.52\%); and UR-Cd (27.31 - 43.70\%), UR-Pb (20.00 - 40.15\%). Overall, the decrease in DY for 2,4-D degradation with increasing Cd and $\mathrm{Pb}$ doses and the relatively low $\mathrm{DE}(<50 \%)$ of the amendments indicates the suppression and vitiation of the biodegradation process in presence of the metal toxicants.

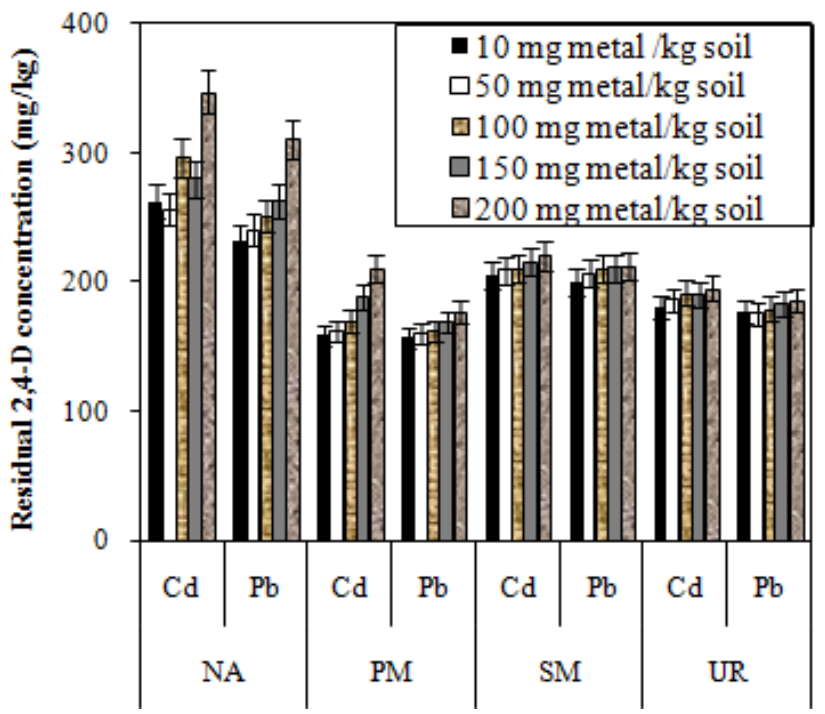

Figure 6: Effect of different doses of $\mathrm{Cd} / \mathrm{Pb}(\mathrm{mg} / \mathrm{kg})$ on 2,4$\mathrm{D}$ (initial concentration $=500 \mathrm{mg} / \mathrm{kg}$ ) dissipation in soil under natural attenuation (NA) or treatment with $(10 \% \mathrm{w} / \mathrm{w})$ poultry manure (PM), swine manure (SM) and urea (UR) after 2 weeks of equilibration.

\section{Conclusion}

This study has demonstrated that even though 2,4-D concentration naturally is attenuated in soil under the conditions investigated, organic amendments did enhance the extent and rate of degradation. Relative to NA, the efficiencies of the amendments generally increased with increase in incubation time and level of amendment, but did not necessarily depend on initial 2,4-D load. Pseudo-firstorder degradation constants ( $\times 10^{-2} /$ day) decreased with herbicide load and increased with adsorbent dosage; with corresponding half-lives (day) decreasing and increasing, respectively. The efficiencies of the single amendments were in the order: $\mathrm{SM}<\mathrm{UR}<\mathrm{PM}$; while those for the binary and ternary blends followed the sequence: $(\mathrm{SM}+\mathrm{UR})<(\mathrm{PM}+$ $\mathrm{SM}+\mathrm{UR})<(\mathrm{PM}+\mathrm{UR})<(\mathrm{PM}+\mathrm{SM})$. The extent of $2,4-\mathrm{D}$ degradation decreased with increasing $\mathrm{Cd}$ and $\mathrm{Pb}$ doses and 


\section{International Journal of Science and Research (IJSR) \\ ISSN (Online): 2319-7064 \\ Index Copernicus Value (2013): 6.14 | Impact Factor (2014): 5.611}

the amendment efficiencies were relatively low $(<50 \%)$ (but more so in the presence of $\mathrm{Cd}$ than $\mathrm{Pb}$ ). This indicates that the biodegradation process was suppressed or vitiated in the presence of metal toxicants.

\section{Acknowledgement}

HCO appreciates the management of National Biotechnology Development Agency, Abuja, Nigeria for the study leave granted her culminating into this research work. The Food and Agricultural Organization (FAO) is appreciated for access to their laboratories in Kaduna, Nigeria.

\section{References}

[1] L.P. Gianessi, "The increasing importance of herbicides in worldwide crop production", Pest Management Science, 69(10), pp.1099-1105, 2013.

[2] L.P. Gianessi, S. Sankula, The value of herbicides in U.S. crop production, National Center for Food and Agricultural Policy, Washington DC. Available from www.ncfap.org, 2003.

[3] V. Cesio, S. Niell, L. Pareja, G. Fernandez, L.G. Asteggiante, B. Bocking, C. García, A.R. FernandezAlba, H. Heinzen, "Critical Revision and Development Perspectives of Herbicide Residues Analysis in Agro Ecosystem", In Kortekamp, A. (Ed.) Herbicides and Environment, InTech, pp. 125-156, Available from: http://www.intechopen.com/books/herbicides-andenvironment/critical-revision-and-developmentperspectivesof-herbicide-residues-analysis-in-agroecosystems, 2011.

[4] M. Graymore, F. Stagnitti, G. Allinson, "Impacts of atrazine in aquatic ecosystems", Environmental International, 26(7-8), pp.483-495, 2001.

[5] R.G. Kanissery, G.K. Sims, "Biostimulation for the enhanced degradation of herbicides in soil", Applied Environmental Soil Science, xxx, 2011.

[6] I. Buchanan, H.C. Liang, W. Khan, "Pesticides and herbicides", Water Environment Research, 81(10), pp.1731-1816, 2009.

[7] J.L. Tadeo, C. Sanchez-brunete, R.A. Perez, M.D. Fernandez, "Analysis of herbicide residues in cereals, fruits and vegetables", Journal of Chromatography, A 882 , pp.175-191, 2000.

[8] H. Kuang, L. Wang, C. Xu, "Overview of Analytical Techniques for Herbicides in Foods", In Larramendy M. (Ed.) Herbicides, Theory and Applications, InTech, pp.239 $-280 . \quad$ Available from: http://www.intechopen.com/books/herbicides-theoryand-applications/overview-of-analyticaltechniques-forherbicides-in-foods, 2011.

[9] M. Cycoń, A. Żmijowska, Z. Piotrowska-Seget, "Biodegradation kinetics of 2,4-D by bacterial strains isolated from soil", Central European Journal of Biology, 6(2), pp.188-198, 2011.

[10]A. Boivin, S. Amellal, M. Schiavon, M.Th. van Genuchten, "Dichlorophenoxyacetic acid sorption and degradation dynamics in three agricultural soils", Chemosphere, 138, pp.92-99, 2005.

[11] J. Gaultier, A. Farenhorst, J. Cathcart, T. Goddard, "Degradation of [carboxyl-14C] 2,4-D and [ring-U-14C] 2,4-D in 114 agricultural soils as affected by soil organic carbon content", Soil Biology and Biochemistry, 40(1), pp.217-227, 2008.

[12] N. Maleki, A. Safavi, H.R. Shahbaazi, "Electrochemical determination of 2,4-D at a mercury electrode", Analytica Chimica Acta, 530(1), pp.69-74, 2005.

[13]F.R. de Andrade, R.A. de Toledo, C.M.P. Vaz, "Electroanalytical Methodology for the Direct Determination of 2,4-Dichlorophenoxyacetic Acid in Soil Samples Using a Graphite-Polyurethane Electrode", International Journal of Electrochemistry, pp. xx 2014. http://dx.doi.org/10.1155/2014/308926.

[14] R. Pal, K. Chakrabarti, A. Chakraborty, Chowdhury, "Degradation and Effects of Pesticides on Soil Microbiological Parameters-A Review", International Journal of Agricultural Research, 1, pp.240-258, 2006.

[15] G.K. Ramdas, K.S. Gerald, "Biostimulation for the Enhanced Degradation of Herbicides in Soil", Applied Environmental Soil Science, pp.xx, 2011.

[16] K.M. Scow, K.A. Hicks, "Natural attenuation and enhanced bioremediation of organic contaminants in groundwater", Current Opinion in Biotechnology, 16(3), pp.246-253, 2005.

[17] N. Kadian, A. Gupta, S. Satya, R.K. Mehta, A. Malik, "Biodegradation of herbicide (atrazine) in contaminated soil using various bioprocessed materials", Bioresource Technology, 99(11), pp.4642-4647, 2008.

[18] A.P. Maxted, C.R. Black, H.M. West, N.M.J. Crout, S.P. McGrath, S.D. Young, "Phytoextraction of cadmium and zinc from arable soils amended with sewage sludge using Thlaspi caerulescens: Development of a predictive model”, Environmental Pollution, 150(3), pp.363-372, 2007.

[19] G.J. Bouyoucos, "Improved hydrometer method for making particle size analysis of soils", Agronomy Journal, 54, pp.464-465, 1962.

[20]B.A. Schumacher, "Methods for the determination of total organic carbon in soils and sediments", USEPANCEA-C-1282, EMASC-001, pp.1-21, 2002.

[21]ISO 13878, "Soil quality - Determination of total nitrogen content by dry combustion (elemental analysis).

[22]USEPA, "Standard Operating Procedure for Total Phosphorous in Sediments by Persulfate Oxidation Digestion (Lachat Method)", 2004.

[23] E.E. Golia, N.G. Tsiropoulos, A. Dimirkou, I. Mitsios, "Distribution of heavy metals of agricultural soils of central Greece using the modified BCR sequential extraction method", International Journal of Environmental Analytical Chemistry, 87(13-14), pp.1053-1063, 2007.

[24] M. Swift, D. Bignell, "Standard methods for assessment of soil biodiversity and land use practice", International Centre for Research in Agroforestry, 2001. Available from http://www.icraf.cgiar.org/sea.

[25] K.M. Durga Devi, C.T. Abraham, N.P. Chinnamma, "Standardisation of procedure for residue analysis of 2,4-D in soil", Journal of Tropical Agriculture, 39, pp.175-177, 2001.

[26] J. Eriksson, A. Andersson, R. Andersson, "The State of Swedish Farmlands", Swedish Environmental Protection Agency, Report 4778, Stockholm, 1997.

[27] M.A. Awodun, "Effect of poultry manure on the growth, yield and nutrient content of fluted pumpkin (Telfaria

\section{Volume 4 Issue 11, November 2015}


occidentalis)", Asian Journal of Agricultural Research, 1, 67-73, 2007.

[28] U.J.J. Ijah, S.P. Antai, "The Potential use of ChickenDrop Micro-Organisms for Oil Spill Remediation”, Environmentalist, 23(1), pp.89-95, 2003.

[29] S.J. Kim, D.H. Choi, D.S. Sim, Y.S. Oh, "Evaluation of Bioremediation Effectiveness on Crude OilContaminated Sand", Chemosphere, 59(6), pp. 845-852, 2005.

[30] I. Maiz, I. Arambarri, R. Garcia, E. Millán, "Evaluation of heavy metal availability in polluted soils by two sequential extraction procedures using factor analysis", Environmental Pollution, 110, pp.3-9, 2000.

\section{Author Profile}

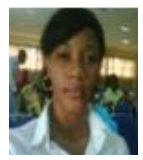

Ms Henrietta C. Ogbu holds a B.Sc in Biochemistry of Enugu State University of Science and Technology and M.Sc Analytical Chemistry of Federal University of Agriculture, Makurdi. She is a Scientific Officer at the National Biotechnology Development Agency, Abuja, Nigeria.

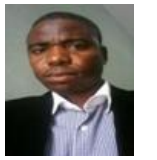

Dr. Raymond A. Wuana holds a B.Sc in Chemistry of the Benue State University (1998). He obtained the M.Sc (Industrial Chemistry) and Ph.D (Analytical and Environmental Chemistry) both from the University of Benin, Benin City, Nigeria in 2004 and 2010, respectively. He is currently an Associate Professor at the Federal University of Agriculture, Makurdi, Nigeria. He has over 42 scholarly publications in journals of international repute spanning the areas of environmental pollution monitoring/analysis and green and sustainable approaches to soil/water remediation.

Dr. John O. Igoli is Senior Lecturer in the Department of Chemistry, Federal University of Agriculture, Makurdi. He has also worked at the Institute of Pharmacy and Biomedical Sciences, University of Strathclyde, Glasgow, Scotland, UK as a Research Fellow. He has garnered so much experience in teaching and research in chromatographic and spectroscopic analysis and drug discovery from natural resources. He has over 30 scientific publications based on his experience in structural elucidation of natural compounds and organic molecules using spectroscopic techniques. 